ISSN: 2362-1303 (Paper) | eISSN: 2362-1311(Online)

JOURNAL OF ADVANCED ACADEMIC RESEARCH (JAAR)

January 2015

\title{
Role of Economic Factors in Promoting Dalit Education
}

\author{
Gopal Lamsal $^{1}$ \& Prof. Dr. Ram Krishna Maharjan² \\ ${ }^{1} \mathrm{PhD}$ Scholar, Mewar University, Rajasthan, India \\ ${ }^{2}$ Professor, Tribhuvan University, Kathmandu, Nepal
}

Corresponding Author

Gopal Lamsal

Email: lamsalg33@yahoo.com

\begin{abstract}
The study was conducted to identify the Role of economic factors in promoting Dalit Education. Dalits are socially, educationally, politically and economically backward. Dalits are known as the disadvantage communities who are culturally categorized as the untouchable caste in society. Legally, it is not allowed to do discrimination in spear of social activities on the basis of caste and ethnicity even though it is still in practice. The study was conducted among the 227 Dalit students, 18 guardians and 25 key informant interview group was in-depth interview and discussion in Nawalparasi district of Nepal. Purposive sampling technique was used to select the respondents from the Dalit communities. School enrolled children were participated in this study. Self-reported structured questionnaire was formed in 5 point Likert's scale to collect the perceptual data. Grade wise, mainly grade 5-10 students at least sometimes felt the problem of tiffin money, problem to manage the expenditure of their school's stationeries, problem of one uniform, feeling of sadness when they had no shoes like other friends, feeling of stress when they could not pay the school's fee and problem of one uniform. In all these issues there was highly significant association ( $p=.000$ ) found on perception of different grade Dalit students. From the discussion, it was found that the Role of economic factors in promoting Dalit Education.
\end{abstract}

Keywords: Dalit, Education, Role, economic, factor, promote

\section{Introduction}

Education is something which must to be brought within the reach of everyone. 'The object of primary education is to see that every child that enters the gateways of a primary school does permission it only at a stage when it becomes literate and continues to be literate throughout the rest of his life.'-B. R. Ambedkar.

Therefore, education can be considered as the instruments that can bring the social change and economic transformation in the country. It leads the country in the path of development. Similarly, it plays the decisive role in the overall process of development like social advancement and economic betterment. UDHR has declared the education is not only national 
ISSN: 2362-1303 (Paper) | eISSN: 2362-1311(Online)

JOURNAL OF ADVANCED ACADEMIC RESEARCH (JAAR)

January 2015

but also international birth right of every child. Nepal has also signatures in that acts but in practice, there is no accessibility, availability and freedom in education in Nepal. The overall literacy of the country is 65.9 percent to male 75.1 percent and female 57.4 the highest literacy rate reported Kathmandu district 86.3 percent and lowest in Rautahat 41.7 percent (CBS, 2014).

The current policy (focuses on education) is not only based on education but also- the adherence to the "child's right to develop its personality, talents, physical and mental abilities to its fullest potential" (Chr\&Gj, Feb-23, 2009) article- 29. Education is also generally considered as a key factor. In reducing poverty and child labour and in promoting new democracy, peace, tolerance and development (UNICEF) both approaches largely draw their attention away from the approaches of parents and children themselves. Efforts have been directed instead towards sensitizing uneducated masses of their "Rights to education." and "The importance of education" yet not much is known about how exactly uneducated people perceive education as a tool for their own family's subsistence or advancement. What future expectations and aspirations do parents have for their children?

Nepal has many characteristic features. Among them, the researcher focuses on the backward poor community as treated untouchable Dalit's Community, Nepal's religious and cultural value which bears high and low caste. Even though uneducated community it is also burning issues until today. Education plays a crucial role to develop their languages, dialects, literatures, arts, scripts, religion etc. The educated people can maintain and sustain the cultural diversities and national unity so empowering indigenous communities providing education, health, employment opportunities, organized public education in Nepal has completed all most five decade several experiment have been done. (Harbinson \& Myers, 1964) Say "education opens the door of development in all fields". They develop the indicators of human capital and compare these with economic development \& predictability by choosing different indicator products different result but the overall correlation between greater human capitals \& greater level of economic rebutted. In economics the more we invest the more we get in return. By using that philosophy, most of Government, NGOs and INGOs were provided many opportunities for the empowerment of Dalit's fifty years ago but all the efforts are almost useless (Koirala B. , 1996). Thus, the researcher wants to seek as to what types of education can empower the Dalit community. Education should be vocational, employ generating, practical, behavioural, earning activities of behaviours change that broke the remaining vicious circle of inequality. It is essentially formal, non-formal and informal education and trainings are needed which help not only the youth but also an adult group of ethnic and Dalit community.

The present research proposal wants to focus on the impact of education in empowering among the group of people in Nepal. Who are for centuries have been treated untouchable caste(Chhuna nahune tatha paninachalne Jat) other people whom so-called high caste can't touch or can't take food from them and uses of the term "Dalit". The word "Dalit" is derived from the 
ISSN: 2362-1303 (Paper) | eISSN: 2362-1311(Online)

JOURNAL OF ADVANCED ACADEMIC RESEARCH (JAAR)

Sanskrit literature and used in political and social scientists in Nepal to identify the category of a group who are socially, culturally, economically, religiously oppressed (Koirala B., 1996). The word Nepali Dalit as similar as the word scheduled caste. The Indian and British governments used the term-scheduled caste for the first time in 1935 (Commission, 1927). In India Harijan (The child of God) is the same so-called untouchable lower caste but in Nepal the word Dalit is widely used in a society to society. In Nepal national Legal code of 1854, the Muluki Ain formulated on the basis of Hindu orthodoxy included five hierarchical categories. They are Tagadhari, Matyali, Alcohol drinkers, impure but touchable and next is untouchable caste (Barr, Durston, Jenkins, Onoda, \& Pradhan, June, 2007, pp. 2,3) from whom water is not acceptable and whose touch requires sprinkling of holy water. As in India, Nepal has no single definition schedule of castes. Different Dalit organizations such as Dalit Vikas (committee formed in 1997, and the National Dalit (commission have defined different groups as belong to the Dalit caste. NDC proposed (bills, 2003, p.2) is defined "Dalit community as communities who have been left behind in social, economic, educational, political and religious spheres and deprived from the human dignity and social justice due to caste based discrimination and untouchability. First chairperson of the NDC describes, "Actually, Dalit is not a caste and caste groups but it is the exclusionary, situation of poor people that made by the so- called upper class, clever groups who rules people in the society. Consequently, they are socially excluded, politically neglected, educationally deprived of, economically exploited and religiously oppressed. They are victimized community previously. They had called untouchable or Sudra but now called as Dalit" (January 12, 2009 Kathmandu Nepal). But the researcher focuses is limited to three Nepali speaking Dalit caste groups. Musahar, Kami, Damai, traditionally Damai is tailor, caste and musician. A kami is blacksmith and a Musahar is nomadic fish keeping and Banihari in the land of Jamindar for their livelihood. The country's population for a total, Damai has $472862(1.8 \%)$, Kami has 1,258,554 (4.8 \%), and Musahar has 234490 (0.8\%) (CBS, 2012, p. 144). Of the 20\% Dalits (Nepal national plans commission). Dalit women and men suffer equally from the practice but Terai Dalit face more discrimination and worse than those living in the hills (Bennett, 2006).

All three castes are dominant Hindu religious and culture. In Nepali Hindu society Dalit are generally disadvantaged and poor than the other people. In Nepal 20 percent of people are in Dalit community. They are mostly below poverty line. The researcher wants to seek how Dalit can be empowered. As the date fluctuates, the number of the Dalit population also varies according to differences. Estimates range from 12 percent to over 20 percent (NDC), (Bennett, 2006) has determined 11.8 percent (CWIN, 2005), Sixteen percent of the total population. Human Rights Watch Group (2004), 21 percent. Centre Human Rights and Global Justice (2005) 20 percent of Nepal's Dalit populations. By the result of that are three cases. Among them one that may include or exclude in the groups two may Dalit have changed their caste three respondents themselves don't want to be identified as Dalit. 
ISSN: 2362-1303 (Paper) | eISSN: 2362-1311(Online)

JOURNAL OF ADVANCED ACADEMIC RESEARCH (JAAR)

January 2015

\section{Method}

This article deals with most of the procedures adopted for the fulfilment of the statement. It includes research design, population and sampling, tools, validation; data collection procedure, data analysis and interpretation of the study are as following.

The methodology used in this study is both qualitative and quantitative in nature. This study is based mainly on qualitative and descriptive design. Therefore, primary and secondary data were collected from various sources. For the help of population and sampling I chose Nawalparasi district the western region of Nepal. The field was rural and urban community schools where purposing Dalit students are schooling. Among them 227 schooling Dalit children are involved with my research questionnaires and observations, 18 their guardians and 25 key informant's interview were involved that interview and 13 case study. The study was conducted 14 community schools and 8 VDCs and only one municipality of Nawalparasi district. The study only focuses how and in what way Dalit communities empower through current schooling system of Nepal. For reliability and validity tools were developed in consultation with the resource persons and developed tools were pre-tests to ensure their reliability and validity. Datas were verified through cross tab and using SPSS method. Mostly primary data were using in the article. After filtering data I described and interpretation them in according to my field experience.

\section{Results}

Poverty is enemy of life. One of the philosophers has said 'To be a thief better than a Pauper'. God has given your life then it is your duty to survive it. So, first people think about their livelihood then other creativity. As the National data of Nepal; 25.2\% (2011 est.) people are living below poverty line. Among them; majority are falls under the Dalit and Janjati (Ethnic groups). So, it becomes the barriers for educational development of Dalit community also.

\section{Managing the Tiffin money}

Regarding these problem, researcher asked the Dalit students about their economic status to manage their tiffin expenditure.

The data shows that $8.4 \%$ said that their parents could not manage their money for tiffin for school followed by $7.9 \%$ said quite often, $48.9 \%$ said sometimes, $6.6 \%$ said hardly ever and $28.2 \%$ said never. From the data, it is know that more than $65 \%$ had problem to manage the daily expenditure of tiffin in schools, which may affect their school education.

Table 1: Managing the Tiffin money

\begin{tabular}{|c|c|c|c|c|c|c|}
\hline \multirow[t]{2}{*}{ Grade } & \multicolumn{4}{|c|}{ Parents do not give tiffin money } & \multicolumn{2}{|c|}{ Total } \\
\hline & Never & Hardly ever & Sometimes & \begin{tabular}{|l|l|} 
Quite Often Very Often \\
\end{tabular} & \# & $\%$ \\
\hline
\end{tabular}


ISSN: 2362-1303 (Paper) | eISSN: 2362-1311(Online)

JOURNAL OF ADVANCED ACADEMIC RESEARCH (JAAR)

\begin{tabular}{|c|c|c|c|c|c|c|c|}
\hline Four & 1 & 1 & 0 & 0 & 0 & 2 & 0.9 \\
\hline Five & 1 & 5 & 1 & 0 & 0 & 7 & 3.0 \\
\hline Six & 3 & 0 & 17 & 1 & 3 & 24 & 10.6 \\
\hline Seven & 9 & 3 & 20 & 2 & 5 & 39 & 17.2 \\
\hline Eight & 21 & 1 & 44 & 8 & 7 & 81 & 35.7 \\
\hline Nine & 26 & 5 & 28 & 7 & 4 & 70 & 30.8 \\
\hline Ten & 3 & 0 & 1 & 0 & 0 & 4 & 1.8 \\
\hline Total & 64 & 15 & 111 & 18 & 19 & 227 & 100 \\
\hline$\%$ & 28.2 & 6.6 & 48.9 & 7.9 & 8.4 & 100 & \\
\hline \multicolumn{8}{|c|}{ Chi-Square Tests } \\
\hline & & & Value & df & \multicolumn{3}{|c|}{ Asymp. Sig. (2-sided) } \\
\hline \multicolumn{3}{|c|}{ Pearson Chi-Square } & $77.115^{\mathrm{a}}$ & 24 & \multicolumn{3}{|c|}{.000} \\
\hline
\end{tabular}

Sources: Field survey, 2014

Grade wise, mainly grade 5-10 students at least sometimes felt the problem of tiffin money. There is significant association $(\mathrm{p}=.000)$ found on perception of different grade students on managing the daily expenditure of their tiffin in school by their parents.

\section{Problem of money for stationary}

Without adequate availability of stationary; books, copies, pencils, schools bag, education of students cannot be effective. These things can support to motivate the students also.

Table 2: Problem of money for stationary

\begin{tabular}{|c|c|c|c|c|c|c|c|}
\hline \multirow[t]{2}{*}{ Grade } & \multicolumn{5}{|c|}{ Problem of money for stationary } & \multicolumn{2}{|c|}{ Total } \\
\hline & Never & Hardly ever & Sometimes & Quite Often & Very Often & \# & $\%$ \\
\hline Four & 0 & 2 & 0 & 0 & 0 & 2 & 0.9 \\
\hline Five & 3 & 4 & 0 & 0 & 0 & 7 & 3.0 \\
\hline Six & 14 & 1 & 2 & 0 & 7 & 24 & 10.6 \\
\hline Seven & 29 & 3 & 3 & 0 & 4 & 39 & 17.2 \\
\hline Eight & 33 & 10 & 24 & 4 & 10 & 81 & 35.7 \\
\hline Nine & 25 & 13 & 25 & 5 & 2 & 70 & 30.8 \\
\hline Ten & 0 & 3 & 0 & 0 & 1 & 4 & 1.8 \\
\hline Total & 104 & 36 & 54 & 9 & 24 & 227 & 100 \\
\hline$\%$ & 45.8 & 15.8 & 23.8 & 4.0 & 10.6 & 100 & \\
\hline \multicolumn{8}{|c|}{ Chi-Square Tests } \\
\hline & & & Value & Df & \multicolumn{3}{|c|}{ Asymp. Sig. (2-sided) } \\
\hline \multicolumn{3}{|c|}{ Pearson Chi-Square } & $76.330^{\mathrm{a}}$ & 24 & \multicolumn{3}{|c|}{.000} \\
\hline
\end{tabular}

Sources: Field survey, 2014 
ISSN: 2362-1303 (Paper) | eISSN: 2362-1311(Online)

JOURNAL OF ADVANCED ACADEMIC RESEARCH (JAAR)

January 2015

The above table no. 2 shows that $10.6 \%$ Dalit students had very often faced the problem of money for stationary whereas $45.8 \%$ said that they had never faced such problem. Similarly, $15.8 \%$ said hardly ever followed by $23.8 \%$ had sometimes and $4 \%$ had quite often faced problem of money for stationary. Around 38\% students from grade 6-10 had reported that they had to face frequently problem of money to manage their stationeries.

There is highly significant association $(\mathrm{p}=.000)$ found on perception of different grade students on problem to manage the expenditure of their school's stationeries.

\section{$\underline{\text { Have one uniform }}$}

Now a day, even in public school has also system of Uniform. In reality, the Uniform system came into existence to reduce the economic stratification of rich and poor in schools premises. But, in some cases, purchasing of simple uniform is also become more expensive for poor people whose daily income is very low and limited only to manage the hand to mouth problem of family. Hardly, parent can be able to purchase the single uniform yearly for their children.

The problem could be observed among the disadvantage and marginalized community in Nepal. From this study, data shows around $44 \%$ had reported that basically they had only one uniform for a year whereas $47.1 \%$ said that they had never faced such problem of single uniform for one whole year. $8.8 \%$ said that hardly ever they had to manage by only one uniform.

Table 3: Have one uniform

\begin{tabular}{|l|l|l|l|l|l|l|l|}
\hline \multirow{2}{*}{ Grade } & \multicolumn{5}{|c|}{ Have one uniform } & \multicolumn{2}{|c|}{ Total } \\
\cline { 2 - 9 } & Never & Hardly ever & Sometimes & Quite Often & Very Often & $\#$ & $\%$ \\
\hline Four & 1 & 1 & 0 & 0 & 0 & 2 & 0.9 \\
\hline Five & 3 & 4 & 0 & 0 & 0 & 7 & 3.0 \\
\hline Six & 7 & 3 & 6 & 1 & 7 & 24 & 10.6 \\
\hline Seven & 21 & 2 & 7 & 4 & 5 & 39 & 17.2 \\
\hline Eight & 42 & 5 & 16 & 6 & 12 & 81 & 35.7 \\
\hline Nine & 33 & 5 & 8 & 10 & 14 & 70 & 30.8 \\
\hline Ten & 0 & 0 & 2 & 1 & 1 & 4 & 1.8 \\
\hline Total & 107 & 20 & 39 & 22 & 39 & 227 & 100 \\
\hline$\%$ & 47.1 & 8.8 & 17.2 & 9.7 & 17.2 & 100 & \\
\hline \multicolumn{7}{|c|}{ Chi-Square Tests } \\
\hline Pearson Chi-Square & Value & df & Asymp. Sig. (2-sided) \\
\hline
\end{tabular}

Sources: Field survey, 2014

On the basis of grade of students; from grade 6-10 had reported that they had very often faced the problem of one uniform. 
ISSN: 2362-1303 (Paper) | eISSN: 2362-1311(Online)

JOURNAL OF ADVANCED ACADEMIC RESEARCH (JAAR)

There is highly significant association $(\mathrm{p}=.006)$ found on perception of different grade students on problem of one uniform.

\section{Feeling sadness when comparing shoes with others friends}

It is general understanding that dressing of man determines his economic status so people want to be luxurious to show their status in society. Basically, children are more interested to get new clothes, shoes and other fashionable goods. Children sometimes feel inferior if they have no adequate facilities as their friends have which gives them mental tension as well as parents also feel pain being unable to fulfil the interest of their children.

Regarding such types of feeling; researcher asked to Dalit-students that whether they felt sadness when they had no shoes like other non-Dalit friends. The following data (table no. 4) shows $59 \%$ said that they never felt any sadness or inferiority when they had no shoes like other friends whereas $10.1 \%$ said that very often they felt such sadness. Similarly, 5.7\% reported that hardly ever followed by $21.1 \%$ reported sometimes and $4 \%$ reported quite often.

Table 4: Feeling sadness when comparing shoes with others friends

\begin{tabular}{|l|l|l|l|l|l|l|l|}
\hline \multirow{2}{*}{ Grade } & \multicolumn{9}{|c|}{ No shoes like others } & \multicolumn{2}{c|}{ Total } \\
\cline { 2 - 9 } & Never & Hardly ever & Sometimes & Quite Often & Very Often & \# & \% \\
\hline Four & 1 & 1 & 0 & 0 & 0 & 2 & 0.9 \\
\hline Five & 6 & 0 & 0 & 0 & 1 & 7 & 3.0 \\
\hline Six & 4 & 1 & 15 & 0 & 4 & 24 & 10.6 \\
\hline Seven & 23 & 1 & 10 & 1 & 4 & 39 & 17.2 \\
\hline Eight & 58 & 4 & 6 & 5 & 8 & 81 & 35.7 \\
\hline Nine & 40 & 6 & 17 & 3 & 4 & 70 & 30.8 \\
\hline Ten & 2 & 0 & 0 & 0 & 2 & 4 & 1.8 \\
\hline Total & 134 & 13 & 48 & 9 & 23 & 227 & 100 \\
\hline$\%$ & 59.0 & 5.7 & 21.1 & 4.0 & 10.1 & 100 & \\
\hline \multicolumn{7}{|c|}{ Chi-Square Tests } \\
\hline Pearson Chi-Square & Value & Df & Asymp. Sig. (2-sided) \\
\hline
\end{tabular}

Sources: Field survey, 2014

On the basis of grade of students; from grade 5-10 had reported that they had very often felt sadness when they had no shoes like other friends.

There is highly significant association $(\mathrm{p}=.000)$ found on perception of different grade students on feeling of sadness when they had no shoes like other friends.

\section{Feeling of stress when they cannot pay school fees}


ISSN: 2362-1303 (Paper) | eISSN: 2362-1311(Online)

JOURNAL OF ADVANCED ACADEMIC RESEARCH (JAAR)

Stress is mental activity constructed due to negative effect of internal or external environmental factors. One student cannot be concentrated on study when they have stress in mind. Stress makes people ill as well as destroys the creativity. Sometimes in daily life, people become the victim of stress because of the interrelationship between the family members, neighbour and friends. Basically in children or teenage; people want the similar luxurious life as their neighbour or friends have. In Nepal, majority of median and low class people suffered by the economic problem.

Table 5: Feeling of stress when they cannot pay school fees

\begin{tabular}{|l|l|l|l|l|l|l|l|}
\hline \multirow{2}{*}{ Grade } & \multicolumn{5}{|c|}{ Cannot pay school fees } & \multicolumn{3}{c|}{ Total } \\
\cline { 2 - 9 } & Never & Hardly ever & Sometimes & Quite Often & Very Often & $\#$ & \% \\
\hline Four & 1 & 0 & 1 & 0 & 0 & 2 & 0.9 \\
\hline Five & 3 & 0 & 2 & 0 & 2 & 7 & 3.0 \\
\hline Six & 6 & 2 & 14 & 2 & 0 & 24 & 10.6 \\
\hline Seven & 14 & 2 & 21 & 2 & 0 & 39 & 17.2 \\
\hline Eight & 56 & 3 & 11 & 5 & 6 & 81 & 35.7 \\
\hline Nine & 39 & 8 & 12 & 5 & 6 & 70 & 30.8 \\
\hline Ten & 2 & 0 & 0 & 0 & 2 & 4 & 1.8 \\
\hline Total & 121 & 15 & 61 & 14 & 16 & 227 & 100 \\
\hline$\%$ & 53.3 & 6.6 & 26.9 & 6.2 & 7.0 & 100 & \\
\hline \multicolumn{7}{|c|}{ Chi-Square Tests } \\
\hline Pearson Chi-Square & Value & df & Asymp. Sig. (2-sided) \\
\hline
\end{tabular}

Sources: Field survey, 2014

The Dalit-education can be affected by their economic status so Dalit-students were asked about their feeling of stress when they could not pay school fees in time or never. The data shows that $53.3 \%$ had never felt stress when they could not pay school fees whereas $7 \%$ said that very often they felt stress during the time of payment of school fees. Similarly, 6.6\% said that they felt hardly ever followed $26.9 \%$ said sometimes and $6.2 \%$ said that quite often they felt stress (Table no.5).

On the basis of level of education, even grade 5 - 10 students felt very often stress during the payment of school fees.

There is highly significant association $(\mathrm{p}=.000)$ found on perception of different grade students on feeling of stress when they could not pay the school's fee. 
ISSN: 2362-1303 (Paper) | eISSN: 2362-1311(Online)

JOURNAL OF ADVANCED ACADEMIC RESEARCH (JAAR)

January 2015

\section{Discussion}

The working paper on "Hostel Schemes for Dalit Students: Inclusive and Incentive Orient for Higher Education?" Is a part of the study of impact assessment of scheduled caste welfare programmers? (George \& Naseem, 2010). It highlights serious flaws in service delivery and reiterates the fact that though several incentive schemes to encourage SCs/STs students for attainment of quality education exist, practices beyond policies remain critical questions as ever. This work, drawing this paper from an assessment study of Babu Jagjivan Ram Chhatravas Yojana, highlights how wrong exclusion occurs even in a targeted scheme. Using available data, the paper argues that the scheme has not adequately followed the stated preferential criteria of low literacy and focus of middle and secondary level of education for SCs females while selecting locations. Most importantly, the scheme does not include poverty as a criterion for selection of beneficiaries, which allows wrong exclusion on a large scale. Despite several policy and programmes interventions to help improve the educational conditions of scheduled castes (SCs) and scheduled tribes (STs) in India, serious gaps exist in their literacy rate, participation in higher, technical and professional education as compared to other social groups, which is more a paradox than the query. The paper suggests that segregation of data across middle, secondary and higher education of SCs male and female in rural and urban India by level of poverty is a practical option to select locations and beneficiaries as long as the scheme has budget constraints for universal coverage. The paper also looks at the extent to which the hostel scheme acts as an incentive for SCs students to continue their education, which is one of its major objectives.

The working in very better because the poor students who are not afford lodging and fooding problem it is concerned higher level of students in the Indian context. But there is gape my article is in western Nepalese rural, urban and terrain context whereas basic level of students, their guardians and local level of KII group are gathered in my case study it is real class room centred. It focuses how can the Dalit communities' people manage their economic problem even though they are mostly unemployment, landless and traditional behaviour?

It is renowned on rural education schemes helping Scheduled Castes (SCs) and the Scheduled Tribes (STs) in rural India (Boxx, October, 2012). Even less is known about how to increase educational opportunity, especially for the most marginalized groups, such as the semi-nomadic, Dalit Community or ethnic community of Kanjars. This study hopes to enlighten new opportunities of addressing social and gender inequality within marginalized SCs and STs through education. Pardada Pardadi Educational Society (PPES) is an innovative, nongovernmental organization (NGO) that is addressing gender inequality, poverty and education. Since 2010, PPES has attempted in a novel approach to convince Kanjar families to send their daughters to school by providing an incentive package that focuses on socialization, hygiene and literacy and later academics. In a specially designed project for the Kanjars, PPES built a 
ISSN: 2362-1303 (Paper) | eISSN: 2362-1311(Online)

JOURNAL OF ADVANCED ACADEMIC RESEARCH (JAAR)

hygiene complex (toilets and showers) creating a tangible community link to the benefits of education. Moreover, children with good attendance are rewarded with a solar light providing lighting in a community without electricity. The results of these projects on the retention of Kanjar girls in school are promising but there is still a long way to go.

At this time India is in need of specific educational strategies for resolving obvious inequalities, including gender inequality of the most historically marginalized groups of their society (Boxx, October, 2012). To the researcher's opinion it seems that the Indian government is not acting conclusively enough on the issue of girl child education, especially for children from STs and SCs. Scholarships alone are not enough, given the lack of real demand within the community for educational opportunities. More clear links must be drawn and true opportunities created for these groups that really incentivize education for both girls and boys. Additionally, health education programs for these communities are in terrible need as well. Moreover, educational schemes must not only provide the best practices possible but also address the root causes of marginalization. The group of rural Uttar Pradesh Kanjars surveyed for this research are symbolic of several groups of lower caste peoples living in rural India and it is hoped that the information presented will help to lighten some of the difficulties associated with their inclusion in educational programs. Nevertheless, more research is greatly needed.

In the same case, the Dalit of Nepal can be empowered through education and other incentive packages. Such as lodging, fooding, clothing, housing and educational instruments is essential in the case of Nawalparasi district.

The model for the right to primary education, free of charge, is established by international instruments, notably Article 4 (a) of UNESCO's Convention against Discrimination in Education, and Articles 13 and 14 of the International Covenant on Economic, Social and Cultural Rights. Article 13 (2) the international covenant accepts clearly the right of every one to primary education, free of charge. Likewise, Article 14 lays down State commitments for a detailed plan of action for the progressive implementation of the right to compulsory education, free of charge, for all. These obligations are similar to the political commitments made under the Dakar Framework for action regarding the national action plan of EFA, (UNESCO, 2008).

In the plan of action for primary education, the United Nations Committee on Economic, Social and Cultural Rights (CESCR) has interpreted the right to compulsory primary education, free of charge, for all members in its General Comment No. 11 (1999) as well as No. 13 (1999). The General Comment No11 states that the nature of this requirement for primary education free of charge is unquestionable. Article 13(2) (a) General Comment No. 13 states that the obligation to provide primary education for all is an immediate (para. 51) and core obligation (para. 57) of these States. 
ISSN: 2362-1303 (Paper) | eISSN: 2362-1311(Online)

JOURNAL OF ADVANCED ACADEMIC RESEARCH (JAAR)

Article 13(2) (a) of the International covenant has stated that primary education has two distinctive features: "compulsory" and "available free to all". Compulsory schooling means that neither parents, nor guardians, nor the State is entitled to treat as optional the decision as to whether the child should have access to primary education. In order to ensure universal primary school attendance, States Parties are obliged to set the minimum working age at no less than 15 years, (Para. 41; see also Article 2 (3) of ILO Convention No. 138 (1973) concerning Minimum Age for Admission to Employment) and to ensure that communities and families are not dependent on child labour (General Comment No. 13, Para. 55).

CESCR has interpreted the requirement that primary education be available free for all. It has clearly stated that States Parties must ensure the availability of primary education, without charge to the child, parents or guardians (General Comment No. 11, Para. 7).

To make compulsory primary education truly free for all children, States Parties are thus grateful to eliminate all direct and indirect costs of schooling. Direct costs such as school fees imposed by the government, local authorities or schools run counter to the international obligations and must be eliminated. However, the indirect costs such as expenses for schoolbooks, uniforms or travel to and from school may be permissible but subject to the examination. Currently, the heaviest charge on a family's budget is from the indirect costs, notably for parents' compulsory contributions (Shiwakoti, 2009).

National Framework to Ensure Free and Compulsory Primary Education Government of Nepal has been making efforts for Free and Compulsory Primary Education (FCPE) since the beginning of the nineties. The piloting of free and primary education was carried out in Banepa Municipality of Kavre district and Ratna Nagar Municipality of Chitwan district in 1995/96. The Local Self Government Act was introduced in 1999, on the above background, of which FCPE was later extended to Chitwan and Ilam districts. The main objective of this program was to ensure education for all including the disadvantaged groups.

The Education for All (EFA) program has given special attention to the schooling of disadvantaged groups. One of the goals of EFA program was to ensure basic education of quality for all children, particularly girls, Dalit, disabled and children in difficult circumstances and children belonging to ethnic minorities, through free and compulsory primary education in Nepal by 2015 .

To ensure basic education for disadvantaged groups, the government introduced several supportive measures at different times. It included free textbooks, scholarship schemes for Dalit girls (50 percent) and disabled, school feeding program, alternative schooling program including school improvement and expansion program in the areas of low enrolment (Shiwakoti, 2009).

Confirming clearly obligation to the child's right to receive quality basic education of up to Grade 8, the core document of School Sector Reform (SSR) has stated that adequate 
ISSN: 2362-1303 (Paper) | eISSN: 2362-1311(Online)

JOURNAL OF ADVANCED ACADEMIC RESEARCH (JAAR)

arrangements will be made to ensure free education to children from economically disadvantaged communities and children with disabilities. SSR has stated that free education will be implemented from the 2009 academic year in Grade 6 and gradually extended up to Grade 10. In the bright of all these, this study intends to analyse the educational status as well as provisions required, measures and process that are essential to ensure the rights of the disadvantaged groups to receive quality basic education.

The study report Shiwakoti and his team clearly defined about free and compulsory education can help the expansion and improvement of education so the report is very well in encouraging education related scholars but There is a gap in the study report and this article their studies report cannot explained about what are economic factors and how can economic factors affecting in promoting Dalit education if the parents have had adequate, economic resources, the schooled teaching and learning environment is adequate, available, accessible, acceptable and adaptable all kind of technical difficulties and obstacles of education for Dalit can be promoted. Their studies are general for all Nepalese contexts but this article specified in the case of Nawalparasi district.

Schooling of Dalit Children in India (Nambissan, 1996, pp. 1011-1024)the educational backwardness of the Dalit communities is generally attributed to poverty and illiterate home environments existing among them. This article draws attention to the effect the learning environment within the formal educational system which has been having on the Dalit pupils. It argues that' besides poor infrastructural facilities, lack of effective pedagogic supports to acquire linguistic, numerical and cognitive competencies harmfully affect the schooling of Dalit children. More importantly, in spite of active encouragement from poor family members, the indifferent treatment by teachers and school administrators largely shape the learning experiences of these socially disadvantaged groups. By creating a separate sphere of non-formal education if or such groups, the government of late has renounced its responsibility to generate equity within the formal school system

It has been claimed that School Feeding Programs increase school participation among poor and food insecure group of people (Dheressa, 2011). This study investigates if the program has significant positive impact on school enrolment, class attendance, and student drop-out patterns among primary school children in DaraWoreda of Sidama Zone, Southern Ethiopia. Data were collected from individual stakeholders. Household Questionnaire, Key Informant Interviews and Observation were the methods employed to collect the data. The quantitative data have been analysed, and then whereas the qualitative data are analysed along with the quantitative results. The study found significant positive impact of School Feeding Program on the three school participation indicators, although it has some roles with regard to these objectives. The result also shows that the major factors affecting school enrolment are demand for child labour, cost of schooling, obtain ability of school, teaching quality and school infrastructure, distance to school, 
ISSN: 2362-1303 (Paper) | eISSN: 2362-1311(Online)

JOURNAL OF ADVANCED ACADEMIC RESEARCH (JAAR)

the availability of food incentives and safety concerns. Whereas, those affecting class attendance and student drop-out include illness, work for money/food, domestic work, school hour hunger and long distance to school. Besides, it has been determined that even among beneficiary households, the elder household head is less likely that the children get enrolled to school during their primary school ages or will not properly attend class even if enrolled. Meanwhile, absence from classes decreases in both beneficiary and non-beneficiary households when household head education level and household income are higher. However, it is found that neither household head education nor household income have significant effect on student drop-out in recipient households. The study recommends that both the nutritional and economic values of School Feeding Program should be improved in order to significantly enhance school participation.

They studied the next functioning and effectiveness of scholarships and incentives intended for girls and children of disadvantaged communities (Acharya \& Luitel, 2006)Is a good thesis report. They desired to understand various incentive schemes from local perspectives rise from the need to provide policy makers, planners, administrators, educators and donors with important insights to help improve the management of current incentive and scholarship schemes.

They had selected three districts Rasuwa, Saptari and Surkhet (Acharya \& Luitel, 2006) the study used interviews, group discussions, and observation and case studies. They find that all three study districts, most of the respondents agreed that the available scholarships/incentives reached the needy population, but complained that they did not cover all of the needy children. According to the teachers, since the scholarships/incentives have been in place, the girls' enrolment and school attendance have increased in the selected schools. In most cases incentives in the form of food and oil were reported to be the most effective in increasing girls' enrolment and attendance.

The study report is very well but not specified in the case of the role for economic factors in promoting Dalit education. My article is in class room specified and Dalit education. There is an operation all schools activities concerned to family economic situations as like as managing the tiffin money, problem of money for stationary, have one uniform, feeling sadness when comparing shoes with others friends, feeling of stress when they cannot pay school fees etc. All of the factors with in-depth interview explored that it is comparatively empowering than previous years of the schools, VDCs, LDOs office and DEO records of Nawalparasi district of Nepal.

\section{Conclusion}

The study explored from the discussion, was found that the role of economic factors in promoting Dalit Education like felt the problem of tiffin money, problem to manage the expenditure of their school's stationaries, problem of one uninform, feeling of sadness when they had no shoes like other friends, feeling of stress when they could not pay the school's fee and 
ISSN: 2362-1303 (Paper) | eISSN: 2362-1311(Online)

JOURNAL OF ADVANCED ACADEMIC RESEARCH (JAAR)

January 2015

problem of one uninform. Teachers, administration and their colleague's behaviour, can effect on learning of Dalit students. Legally, it is not allowed to do discrimination in spear of economic activities on the basis of poverty, caste, and ethnicity even though it is still somewhat practice most of rural areas of Nawalparasi district. The discriminative behaviour is slowly decaying with the help of huge amount of scholarship for Dalit and Janajati. They are gradually empowered through incentives measures like scholarships, mid-day meals, dresses, inclusive education and reservation policy of government in most of the field in Nepal. Not only government but also NGOs, INGOs, and other local level organizations are supporting Dalit promoting programme.

\section{Acknowledgements}

I express my gratitude to the respondents. Besides that I like to give my thanks to the Mewar University, very most indebted the Chairperson of PhD Scholars Association of Nepal Mr. Tej Bahadur Karki, Academic Advisor of PhD center Prof. Dr. Tatwa P. Timsina, Excellent Scholar Mr. Dasarath Neupane and Southwestern Centre for PhD Studies for their Valuable support and guidance.

\section{References}

Acharya, S., \& Luitel, B. (2006). The Functioning and Effectiveness of Scholarship and Incentive Schemes in Nepal. Kathmandu: UNESCO Office of Kathmandu.

Barr, E., Durston, S., Jenkins, R., Onoda, E., \& Pradhan, A. (June, 2007). Dalit in India and Nepal; Policy Options for Improving Social Inclusion in Education. UNICEF. New York: UNICEF.

Bennett, L. (2006). Unequal Citizens; Gender,Caste and Ethinic Exclusion in Nepal. World Bank, DFID.

Boxx, W. (October, 2012). Addressing Educational Opportunities for Rural Kanjars: Findings from an Educational Incentive Scheme in Anupshahar, Uttar Pradesh, India. Ludwig Maximillian University, Munich, Germany., Anupshahar, Uttar Pradesh.

CBS. (2012). National Population and Housing Census 2011 (National Report). Central Bureau of Statistics., National Planning Commission. Kathmandu: Central Bureau of Statistics Kathmandu, Nepal.

CBS. (2014, Sep). National Population and Housing Census 2011 Caste/Ethnicity. Retrieved from www.http://cbs.gov.np/.

Chr\&Gj, D. I. (Feb-23, 2009). Recasting Justice; Securing Dalit Rights in Nepal's New Constitution. 
ISSN: 2362-1303 (Paper) | eISSN: 2362-1311(Online)

JOURNAL OF ADVANCED ACADEMIC RESEARCH (JAAR)

January 2015

Commission, S. (1927). Scheduled Caste. British: Unpublished Statement.

Dheressa, D. K. (2011). Education in Focus: Impacts of School Feeding Program on School Participation. Norwegian University of Life Sciences (UMB), Department of International Environment and Development Studies (Noragric),. Southern Ethiopia: Unpublished M.A Thesis.

George, S., \& Naseem, D. (2010). Hostel Schemes for Dalit Student How Inclusive and Incentive Oriented for Higher Education. Indian Iunstitude of Dalit studies(IIDS). New Delhi: IIDS,New Delhi.

Harbinson, F., \& Myers, C. (1964). Education, Manpower \& Economic Gorth; Strategies of Human Resource Development. New York: Mc Graw Hill.

Koirala, B. (1996). Schooling and Dalit of Nepal - A Case Study of Bungkot Dalit Community. Alberta University: Unpublished PhD Thesis.

Koirala, B. N. (2010). Late Comers in School: The Status of Dalit Girls in Education". Feminist Dalit Organization, Education. Kathmandu: Feminist Dalit Organization,.

Nambissan, G. B. ( 1996, April 20-27). Equity in Education? Schooling of Dalit Children in India. Economic and Political Weekly, 31, 1011-1024. Retrieved from 4404063

Shivakoti, D. K. (2013). Implementation of Marginalized Group Education Scholarship. Educational, Social Inclusion Research Fund (SIRF)/ SNV Nepal. Bakhundole, Lalitpur: Unpublished.

Shiwakoti, P. D. (2009). Ensuring Free and Compulsory Basic Education for Disadvantaged Groups in the Context of Education for All. Tribhuvan University, Education. Kathmandu: CERED.

UNESCO. (2008). The Right to Primary Education Free of Charge for all: Ensuring Compliance with International Obligations. Paris: UNESCO. 